\title{
Transfer Teknologi Pengeringan Daun Pegagan untuk Masyarakat Desa Bedono, Kecamatan Jambu, Kabupaten Semarang
}

\author{
Victoria Kristina Ananingsih*, Cynthia Andriani, Sumardi, Bernardine Agatha Adi Konstantia \\ ${ }^{1}$ Program Studi Teknologi Pangan, Fakultas Teknologi Pertanian, Universitas Katolik Soegijapranata \\ Jalan Pawiyatan Luhur IV/1, Kecamatan Banyumanik, Semarang, Jawa Tengah, 50234
}

*email : kristina@unika.ac.id

\begin{abstract}
Abstrak-Kelompok masyarakat Raket Suket Desa Bedono, Kecamatan Jambu, Kabupaten Semarang, telah mengumpulkan data tanaman rumput yang tumbuh di kebun Desa Bedono. Kelompok Raket Suket mempunyai keterbatasan pengetahuan tentang kandungan gizi dan fitokimia tanaman rumput, serta pengolahan tanaman rumput menjadi minuman herbal, sehingga memerlukan pendampingan dari tim pengabdian masyarakat Fakultas Teknologi Pertanian Unika Soegijapranata (FTP). Kegiatan diawali dengan survey tanaman rumput di Desa Bedono. Studi pustaka dilakukan terhadap 5 tanaman rumput yang banyak tumbuh dan sering dikonsumsi oleh masyarakat Desa Bedono. Pengolahan dilakukan terhadap tanaman rumput yaitu pegagan (Centella asiatica), dengan cara pengeringan untuk membuat minuman herbal kering daun pegagan. Pengujian parameter kualitas dari minuman herbal pegagan kering dilakukan di Laboratorium yaitu kandungan antioksidan dan total fenol. Hasil studi pustaka dan analisa di Laboratorium (pengujian parameter kualitas) disampaikan kepada perwakilan Kelompok Raket Suket Desa Bedono dalam Transfer Teknologi (online) Pengeringan Daun Pegagan. Kelompok Raket Suket Desa Bedono selanjutnya dapat menerapkan teknologi pengeringan daun pegagan untuk produksi minuman herbal kering yang selanjutnya dapat dipasarkan ke masyarakat luas.
\end{abstract}

Kata kunci-tanaman rumput, pegagan, minuman herbal, pengeringan

Abstract-The Raket Suket community group in Bedono Village, Jambu District, Semarang Regency, has collected data on grass plants that grow in the Bedono Village garden. The Raket Suket Group has limited knowledge about the nutritional and phytochemical content of grass plants, as well as processing grass plants into herbal drinks, so they need assistance from the community service team of the Faculty of Agricultural Technology, Soegijapranata Catolic University (FTP). The activity began with a survey of grass plants in Bedono Village. A literature study was conducted on 5 grass plants that grow a lot and are often consumed by the people of Bedono Village. Processing is carried out on the grass plant, namely pegagan (Centella asiatica), by drying to make a dry herbal drink of pegagan leaves. Testing the quality parameters of the dried pegagan herbal drink was carried out in the laboratory, namely the antioxidant content and total phenol. The results of the literature study and analysis in the laboratory (testing quality parameters) were informed to representatives of the Suket Racket Group in Bedono Village in Technology Transfer (online) for Drying of Pegagan Leaves. The Raket Suket Group in Bedono Village can then apply the technology of drying of pegagan leaves for the production of dry herbal drink which can then be marketed to the wider community.

Keywords—grass plant, pegagan, herbal drink, drying

\section{PENDAhUluan}

Pengembangan teknologi pengolahan minuman herbal dan olahan sayuran yang dipelajari di Fakultas Teknologi Pertanian (FTP) Unika Soegijapranata disampaikan kepada Kelompok Masyarakat Raket Rumput Bedono. Hal ini sebagai bagian transfer teknologi yang merupakan tugas akademisi terutama Rumpun Rekayasa Pengolahan Pangan FTP Unika Soegijapranata..

Kelompok masyarakat Raket Suket Desa Bedono memerlukan pendampingan untuk mengetahui informasi kandungan gizi dan fitokimia, serta pengolahan tanamanan rumput menjadi makanan sehat baik minuman herbal ataupun olahan sayur.

Pendampingan teknologi pengolahan sayuran dan minuman herbal tanaman rumput diperlukan bagi kelompok masyarakat Raket Suket Desa Bedono. Di samping itu diperlukan informasi kandungan gizi dan manfaat kesehatan tanaman rumput untuk mencukupi gizi masyarakat yang mengkonsumsinya. Informasi kandungan gizi dan fitokimia 
dilakukan melalui studi literatur dan analisa di Laboratorium FTP Unika Soegijapranata.

Survey awal dilakukan untuk mendata tanaman rumput di Desa Bedono. Dari 60 tanaman rumput yang telah didokumentasikan oleh Kelompok Raket Suket Bedono dipilih 5 tanaman untuk dilakukan studi literatur tentang manfaat gizi, fitokimia dan pengolahannya yaitu : semanggi gunung, cekuthi, jepotan, cempolan dan pegagan. Selanjutnya dipilih tanaman pegagan untuk diolah menjadi minuman herbal kering dengan penerapan teknologi pengeringan.

\section{TANAMAN PEGAGAN}

Tanaman pegagan adalah suatu tanaman yang dapat tumbuh di perkebunan, tepi jalan, tepi sawah, atau pun juga dapat tumbuh di dalam pot. Tanaman pegagan sendiri memiliki tangkai serta daun yang berbentuk seperti pelepah, dengan ukuran panjang 5-15 cm [1]. Daun yang berwarna hijau dan melebar yang bentuknya seperti kipas dengan permukaan yang sedikit licin, tepinya agak melengkung keatas, dan diameternya yaitu antara $1-7 \mathrm{~cm}$. Selain itu, tanaman pegagan juga memiliki buah dan bunga. Bunganya berwarna putih atau merah muda berbentuk seperti payung yang tersusun rapi, sedangkan buah pegagan bentuknya lonjong, memiliki aroma yang harum serta rasanya yang pahit, berwarna kuning, dan berdinding agak tebal.

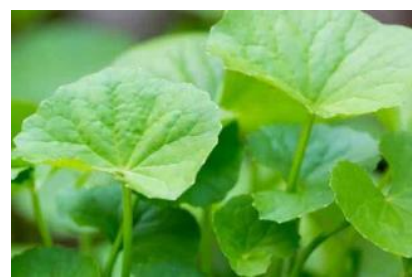

Gambar 1. Tanaman Pegagan

Klasifikasi tanaman pegagan menurut BPOM RI [1] sebagai berikut :

$\begin{array}{ll}\text { Kingdom } & \text { : Plantae } \\ \text { Divisi } & \text { : Magnoliophyta } \\ \text { Sub devisi } & \text { : Rosidae } \\ \text { Kelas } & \text { : Magnoliopsida } \\ \text { Bangsa } & \text { : Apiales } \\ \text { Suku } & \text { : Apiaceae } \\ \text { Marga } & \text { : Centella } \\ \text { Jenis } & \text { : Centella asiatica }(\text { L.) }\end{array}$

Tanaman pegagan (Centella asiatica) adalah suatu tanaman yang tumbuh secara liar dan memiliki manfaat yang cukup baik sebagai obat tradisional. Tanaman pegagan telah ditetapkan sebagai tanaman yang bermanfaat dan dapat digunakan untuk obat tradisional sejak tahun 1884 [2]. Daun pegagan memiliki manfaat sebagai antioksidan sekaligus antibakteri, meningkatkan aktivitas memori, mengatasi radang, memberi efek menenangkan dan meningkatkan fungsi mental menjadi lebih baik [1]. Pada tanaman pegagan terdapat beberapa komponen bioaktif seperti asiatikosida berupa glikosida dan banyak digunakan dalam ramuan obat tradisional atau jamu [3]. Daun pegagan mengandung berbagai bahan aktif, yaitu triterpen, saponin, triterpen genin, minyak atsiri, flavonoid, dan fitosterol [2]. Kandungan bioaktif yang terdapat di dalam tanaman pegagan merupakan antioksidan yang dapat bermanfaat untuk tubuh dan juga dapat meningkatkan sistem imun.

\section{PENGERINGAN TANAMAN PEGAgAN}

\section{A. Pengeringan dengan Cabinet Dryer}

Daun pegagan segar dicuci bersih, dipotong kecil-kecil, dan direndam dengan kalsium klorida $0,5 \%$ selama 15 menit. Daun pegagan selanjutnya dilayukan pada suhu 70oC selama 3 menit menggunakan steam blanching lalu didinginkan selama 5 menit. Daun pegagan kemudian dikeringkan pada suhu $50^{\circ} \mathrm{C}$ selama 3,5 jam menggunakan cabinet dryer hingga didapatkan kadar air $\leq 8 \%$ sesuai SNI teh kering [4].

Pengecilan ukuran daun pegagan dilakukan dengan dipotong kecil-kecil untuk memperbesar luas permukaan. Daun pegagan selanjutnya direndam dalam $\mathrm{CaCl} 20,5 \%$ selama 15 menit lalu dilakukan steam blanching selama 3 menit dan diangin-anginkan selama 5 menit. Pre-treatment ini dilakukan untuk mempertahankan kandungan antioksidan pada bahan yang akan dikeringkan. Daun pegagan yang telah dilayukan selanjutnya dikeringkan menggunakan cabinet dryer di dalam oven binder dengan suhu $50^{\circ} \mathrm{C}$ hingga kadar air $<8 \%$ sesuai syarat mutu SNI 2013 [4]. $\mathrm{CaCl} 2$ 0,5\% merupakan bahan pengeras (firming agent) untuk sayur atau buah. Garam kalsium klorida merupakan elektrolit kuat sehingga mudah larut dalam air dan ion-ion $\mathrm{Ca}$ mudah terabsorpsi ke dalam jaringan yang mengakibatkan dinding sel semakin kuat. Proses steam blanching bertujuan untuk mengurangi efek negatif selama pengeringan seperti mematikan enzim penyebab reaksi browning dan mempersingkat waktu pengeringan. Proses penyeduhan dilakukan dengan menggunakan pelarut air dengan suhu $90^{\circ} \mathrm{C}$ pada daun pegagan kering sebanyak 0,5 gram. Minuman herbal daun pegagan kemudian didiamkan selama 15 menit. Hasil seduhan minuman herbal digunakan untuk pengujian aktivitas antioksidan.

\section{B. Pengeringan dengan Solar Tunnel Dryer (STD)}


Pegagan segar yang telah dipilih dicuci bersih kemudian direndam dengan kalsium klorida 0,5\% selama 15 menit. Selanjutnya, daun pegagan dilayukan pada suhu $70^{\circ} \mathrm{C}$ selama 4 menit dengan steam blanching lalu didinginkan selama 5 menit. Daun pegagan yang telah dilayukan kemudian diiris untuk memperkecil luas permukaan dan untuk mempercepat proses pengeringan. Daun pegagan yang telah dilakukan pengecilan ukuran selanjutnya dikeringkan menggunakan Solar Tunnel Dryer hingga diperoleh kadar air < $10 \%$ [5].

\section{Aktivitas Antioksidan Daun Pegagan Kering}

TABEL I

AKTivitas Antioksidan Daun Pegagan

\begin{tabular}{|c|c|}
\hline $\begin{array}{c}\text { Waktu } \\
\text { Penyeduhan } \\
\text { (menit) }\end{array}$ & \multicolumn{1}{|c|}{ Suhu Pengeringan } \\
\cline { 2 - 2 } & $\mathbf{5 0}^{\mathbf{}} \mathbf{C}$ \\
\hline 0 & $8,636 \pm 0,646 \mathrm{C} 1$ \\
\hline 3 & $10,291 \pm 0,325 \mathrm{C} 2$ \\
\hline 6 & $12,238 \pm 0,535 \mathrm{C} 3$ \\
\hline 9 & $13,120 \pm 0,357 \mathrm{C} 4$ \\
\hline 12 & $15,070 \pm 0,701 \mathrm{C} 5$ \\
\hline 15 & $17,424 \pm 1,358 \mathrm{C} 7$ \\
\hline 18 & $13,790 \pm 0,426 \mathrm{C} 6$ \\
\hline 21 & $13,182 \pm 0,766 \mathrm{C} 5$ \\
\hline 24 & $11,627 \pm 0,623 \mathrm{C} 4$ \\
\hline
\end{tabular}

Antioksidan merupakan senyawa yang mampu menghambat reaksi radikal bebas dalam tubuh. Tubuh membutuhkan antioksidan eksogen seperti vitamin E dan vitamin C ketika terjadi paparan radikal berlebih [6]. DPPH merupakan suatu senyawa radikal bebas yang bersifat stabil. Prinsip dari pengujian DPPH adalah mereaksikan suatu senyawa antioksidan dengan senyawa radikal bebas DPPH. Dalam pengujian aktivitas antioksidan menggunakan reagen DPPH, diguanakan alat spektrofotometer UV-Vis untuk mengukur nilai absorbansi sampel yang diuji [7]. DPPH adalah metode yang dapat digunakan sebagai penentu aktivitas antioksidan dalam sampel dengan melihat kemampuannya dalam menangkal radikal bebas DPPH [7]. Kelebihan metode DPPH adalah sederhana, mudah diterapkan karena senyawa radikal DPPH yang bersifat relatif stabil, cepat, peka, dan tidak membutuhkan sampel yang banyak.

\section{Hasil Pengeringan dan Penyeduhan Daun Pegagan}

Suhu optimal pengeringan daun pegagan pada suhu $50^{\circ} \mathrm{C}$. Semakin lama waktu pengeringan, maka aktivitas antioksidan akan semakin lemah karena sebagian senyawa akan hilang dengan panas [8]. Proses pengolahan seperti pengeringan memberikan pengaruh yang berbeda terhadap uji kapasitas antioksidan. Proses pengeringan akan membantu kandungan senyawa keluar dari dalam daun pegagan. Aktivitas antioksidan tertinggi diperoleh pada sampel yang dikeringkan pada suhu $50^{\circ} \mathrm{C}$.

Pada proses penyeduhan atau infusi, aktivitas antioksidan tertinggi minuman herbal daun pegagan diperoleh pada metode penyeduhan selama 15 menit dengan nilai aktivitas antioksidan sebesar $89,348 \%$. Waktu penyeduhan dapat mempengaruhi aktivitas antioksidan pada minuman herbal. Waktu penyeduhan yang terlalu singkat menjadi kurang efisien karena kandungan antioksidan belum larut secara optimal dan belum mencapai titik yang optimal. Pada penelitian ini, aktivitas antioksidan dalam minuman herbal daun pegagan membutuhkan waktu 15 menit penyeduhan untuk mendapatkan aktivitas antioksidan yang paling optimal. Aktivitas antioksidan mengalami kenaikan dari waktu 0 menit hingga waktu 15 menit dan mengalami penurunan pada waktu 18 menit hingga waktu 24 menit. Penurunan aktivitas antioksidan pada menit ke-18 menit terjadi karena komponen-komponen penyusun antioksidan mengalami kerusakan sehingga dapat menurunkan tingkat aktivitasnya [9].

\section{E. Hasil Perebusan Daun Pegagan}

Pada metode rebusan, aktivitas antioksidan tertinggi minuman herbal daun pegagan diperoleh pada metode rebusan selama 10 menit dengan nilai $84,54 \%$. Suhu awal yang tinggi dapat mempengaruhi jumlah senyawa antioksidan yang terekstrak [10]. Pada penelitian ini, sampel rebus dengan suhu $100^{\circ} \mathrm{C}$ memiliki persen aktivitas antioksidan yang lebih tinggi dibandingkan sampel seduh suhu $90^{\circ} \mathrm{C}$. Lamanya waktu proses preparasi dapat meningkatkan komponen bioaktif yang terekstrak [11].

\section{KESIMPULAN}

Pengolahan dilakukan terhadap tanaman rumput yaitu pegagan (Centella asiatica), dengan cara pengeringan untuk membuat minuman herbal kering daun pegagan. Pengujian parameter kualitas dari minuman herbal pegagan kering dilakukan di Laboratorium yaitu kandungan antioksidan dan total fenol. Hasil studi pustaka dan analisa di Laboratorium (pengujian parameter kualitas) telah disampaikan kepada perwakilan Kelompok Raket Suket Desa Bedono dalam Transfer Teknologi. Pengeringan Daun Pegagan.

Pengolahan minuman herbal daun pegagan terbaik diperoleh pada suhu pengeringan $50^{\circ} \mathrm{C}$ dengan metode penyeduhan dengan waktu penyeduhan 15 menit yang menghasilkan nilai aktivitas antioksidan sebesar $89,348 \%$, serta metode perebusan dengan waktu rebusan selama 10 
menit yang menghasilkan aktivitas antioksidan metode sebesar $84,54 \% \pm 0,81$.

Selanjutnya diperlukan adanya pendampingan secara langsung di Desa Bedono untuk pengolahan herbal kering tanaman rumput menggunakan alat pengering yang sudah dimiliki oleh Kelompok Raket Suket. Kelompok Raket Suket Desa Bedono selanjutnya dapat menerapkan teknologi pengeringan daun pegagan untuk produksi minuman herbal kering yang dapat dipasarkan ke masyarakat luas.

\section{UCAPAN TERIMA KASIH}

Terima kasih kepada Fakultas Teknologi Pertanian dan LPPM UNIKA Soegijapranata yang telah memberikan dukungan pendanaan kegiatan pengabdian masyarakat ini.

\section{DAFTAR PUSTAKA}

[1] Booklet Pegagan Serial Data Ilmiah Terkini, Direktorat Obat Asli Indonesia Badan Pengawas Obat dan Makanan, Jakarta, Indonesia, 2010, pp.1-14

[2] Winarto, W.R. and Surbakti, M., Khasiat dan Manfaat Pegagan, Jakarta: Penerbit Agromedia Pustaka, 2003.

[3] Ietje Wientarsih, et al., "Aktivitas Antioksidan Fraksi Metanol Daun Pegagan", J. Fitofarmaka, vol 3, no. 2, Dec. 2013.

[4] Syarat Mutu Teh kering, SNI 3836:2013

[5] Putrihan, S., "Potensi Drying Agent Dalam Pengeringan Daun Sirsak (Annona Muricata Linn.) Terhadap Karakteristik Fisikokimia Minuman Seduhan Daun Sirsak", Bachelor Thesis, Fakultas Teknologi Pertanian, Universitas Katolik Soegijapranata, Semarang, Indonesia, 2015.

[6] Rohman, A. and Riyanto, S.,"Aktivitas Antiradikal Bebas Ekstrak Kloroform Buah Mengkudu (Morinda citrifolia, L.) dan Fraksifraksinya", J. Agritech. vol.6 no.1,pp. 1-39, 2006.

[7] A. Rahmawati, et al., "Analisis Aktivitas Antioksidan Produk Sirup Buah Mengkudu (Morinda Citrifolia L.) Dengan Metode DPPH”, $J$. Fitofarmaka Indonesia vol. 2, no. 2, pp.97-101, 2015

[8] D. Angraiyati. dan F. Hamzah, "Lama Pengeringan Pada Pembuatan Teh Herbal Daun Pandan Wangi (Pandanus Amarylifolius Roxb.,) terhadap Aktivitas Antioksidan", J.Online Mahasiswa. vol. 4, no. 1, pp. 2-3, 2017.

[9] I Putu Willigis Benito Khatulistiwa, et al., "Pengaruh Suhu Pengeringan Oven Terhadap Aktivitas Antioksidan Bubuk Daun Cemcem (Spondias Pinnata (L.F) Kurz", J. Itepa. vol. 9, no. 3, pp. 350-356, 2020.

[10] Yan Jin, et al, 2019. "Comprehensive Investigation of the Effects of Brewing Conditions in Sample Preparation of Green Tea Infusions", Molecules, vol. 24, no. 1735, pp. 1-12. May, 2019.

[11] A.M. Ibrahim, et al., "Pengaruh Suhu Dan Lama Waktu Ekstraksi Terhadap Sifat Kimia Dan Fisik Pada Pembuatan Minuman Sari Jahemerah (Zingiber Officinale var. Rubrum) Dengan Kombinasi Penambahan Madu Sebagai Pemanis"., J. Pangan dan Agroindustri. vol. 3, no. 2, pp. 530-541, 2015 . 